\title{
A Possible Mechanism of Antidepressant like Effect of Recombinant Human Erythropoietin
}

\author{
Pawar AS ${ }^{1}$, Barve $\mathrm{KH}^{1^{*}}$, Patel $\mathrm{A}^{2}$, Raje $\mathrm{A}^{3}$ and Addepalli VA ${ }^{1}$ \\ ${ }^{1}$ Shobhaben Pratapbhai Patel-School of Pharmacy and Technology Management, SVKM's NMIMS, Mumbai, Maharashtra, India \\ ${ }^{2}$ Wockhardt Research Centre, D-4 Chikalthana, Aurangabad, Dist. Aurangabad, Maharashtra, India \\ ${ }^{3}$ Vimta Labs Ltd., Nallagutta, Secunderabad, Andhra Pradesh, India
}

"Corresponding author: Kalyani Barve, SPP-School of pharmacy and technology management, 5th floor mithibai college building, V.L. Mehta road, Vile Parle, Mumbai 400056, India, Tel- 9920467646; Fax: 91-22-26185422; E-mail: barve.kalyani@gmail.com

Received date: July 18, 2014, Accepted date: Aug 13, 2014, Published date: Aug 20, 2014

Copyright: (C) 2014 Barve $\mathrm{KH}$, et al. This is an open-access article distributed under the terms of the Creative Commons Attribution License, which permits unrestricted use, distribution, and reproduction in any medium, provided the original author and source are credited.

\begin{abstract}
Objective: Recombinant human erythropoietin is clinically proved to have antidepressant like effect. The present study deals with evaluating the possible mechanism of action of the antidepressant effect of recombinant human erythropoietin (rH-Epo).

Methods: The antidepressant activity of subcutaneously administered $\mathrm{rH}$-Epo was tested in models of acute stress and chronic stress. Simultaneous administration of $\mathrm{rH}$-Epo in sub-effective dose with sub-therapeutic doses of standard anti-depressants/agonist and antagonist of various receptors was done in mice to study the potential mechanism of antidepressant effect of $\mathrm{rH}$-Epo using the tail suspension test. One-way or two-way ANOVA, followed by post- Turkey test and Paired $\mathrm{T}$ test were applied wherever appropriate.
\end{abstract}

Results: In acute stress model, $\mathrm{rH}$-Epo produced significant decrease in immobility period in the dose range of 500 - $4000 \mathrm{lU} / \mathrm{kg}$ comparable to standard antidepressant. However dose dependency was not observed. In chronic stress model, animals receiving stress showed significant decrease in rotarod activity, while pre-treated animals with $\mathrm{rH}$-Epo showed improvement in rotarod activity. $\mathrm{rH}$-Epo at sub-effective dose, when combined with sub-therapeutic doses of standard anti-depressants showed significant potentiation of antidepressant action. Antidepressant effect of $\mathrm{rH}$-Epo was completely blocked by therapeutic dose of Pindolol and Haloperidol, whereas clonidine partially blocked it. Animals, pre-treated with sub-therapeutic dose of $\mathrm{rH}-\mathrm{Epo}$ when injected with Yohimbine, showed moderate potentiation of response.

Conclusion: Reversal of chronic stress induced depressive symptoms by $\mathrm{rH}$-Epo treatment is indication of upregulation of serotonergic receptors. There might be involvement of serotonergic and adrenergic system in antidepressant effect of rH-Epo.

Keywords: rH-Epo; Depression; Chronic stress; Tail suspension test; Serotonin; Adrenergic system; Acute stress

\section{Introduction}

Depression is a serious illness and different factors are implicated in the etiology of depression. Existing drugs have undesirable side-effects including receptor desensitization [1], reducing their compliance with therapy, hence new antidepressants are needed.

Erythropoietin (Epo) is a glycoprotein and has receptors present in various parts of the brain [2]. rH-Epo is effective in the treatment of anemias associated with surgery, AIDS, cancer chemotherapy, prematurity, and certain chronic inflammatory conditions. During erythropoietin therapy, absolute or functional iron deficiency may develop. Virtually all patients eventually will require supplemental iron to increase or maintain transferrin saturation to levels that will adequately support stimulated erythropoiesis. It may result into serious thromboembolic and cardiovascular events especially in people undergoing dialysis. Headache, tachycardia, edema, shortness of breath, nausea, vomiting, diarrhea, injection site stinging, arthralgias, and myalgias also have been reported in conjunction with rH-Epo therapy [3]. rH-Epo is involved in decreased production of proinflammatory mediators by modulation of HPA axis which ultimately works through the serotonergic receptors [4].

Thus, rH-Epo may have potential in treating depression like symptoms mediated through regulation of serotonergic receptors [5]. For the present study the effect of rH-Epo on depression was investigated. Furthering the results of this study, an attempt was made to find its mechanism of action by co administration of various receptor agonist/antagonists and standard antidepressants.

\section{Methodology}

\section{Animals}

Male Swiss albino mice (25-30 g) and male Wistar rats (250-280 g) were obtained from animal house facility of Wockhardt Research Centre, Aurangabad, India, where the study was conducted. The animals were housed in standard laboratory conditions. The 
experimental protocols were approved by the Wockhardt Animal Ethics Committee (WAEC).

\section{Chemicals}

Recombinant human Erythropoietin (rH-Epo, Wockhardt Ltd, India), Pindolol, Yohimbine hydrochloride, Haloperidol, Clorgyline (Sigma Aldrich, St. Louis, MO, USA.), Clonidine (UNICHEM Laboratories Ltd, India), Venlafaxine (Wockhardt Ltd., India), Imipramine (Nicholas Piramal India Ltd.), Fluoxetine (Sun Pharma Ltd., India).

rH-Epo was dissolved in Phosphate - Albumin buffered saline. Clorgyline was dissolved in $0.9 \%$ normal saline. Pindolol, Imipramine, Fluoxetin, Venlafaxine were dissolved in $1 \%$ tween 80 and volume was made with $0.9 \%$ normal saline, Haloperidol, Clonidine, Yohimbine were dissolved in 1\% DMSO. Control animals received respective vehicles.

\section{Acute Stress Model}

Antidepressant like activity of rH-Epo was evaluated in despair swim test and tail suspension test in Swiss mice. The rH-Epo was administered at doses of $250,500,1000,2000,4000 \mathrm{IU} / \mathrm{kg}$ by subcutaneous route18 hours prior to testing (Cmax is16 to 20 hours). Venlafaxine $20 \mathrm{mg} / \mathrm{kg}$ i.p. and vehicle were administered 1 hour before the test intra-peritonealy. Tail suspension test was conducted as described by Steru [6]. Animals showing passive behaviour were counted as time in seconds and compared with vehicle treated controls. Despair swim test was conducted as described by Porsolt [7]. Duration of immobility was measured in controls and animals treated with various doses of the test drug or standard [8]. Cumulative activity counts were recorded for mice on a locomotor activity meter every one $\mathrm{min}$ for ten min. Total movements including fast and slow movements for test drug treated groups were added up and compared with standard drug treated group and vehicle control [9].

\section{Chronic Stress Model}

Male wistar rats were subjected to stress regimen two hr daily for 4 weeks in water stress cage. The animals were selected as per the criteria of Mizoguchi et al. [10] In all 40 animals were selected and were divided into two groups as follows:

Group-1: Animals who received chronic stress. $(n=32)$.

Group-2: Animals who did not receive any type of stress $(n=8)$.

All 40 animals received training on rotarod for three days daily for 180 seconds on $20 \mathrm{rpm}$ speed and were subjected to traction test once in a day for three days for 60 seconds. After the training period animals were exposed to chronic stress by placing them in stress cage (dimensions $11.8 \mathrm{~cm}$ length $\times 29.1 \mathrm{~cm}$ width $\times 19.5 \mathrm{~cm}$ height) with wired mesh at its bottom. Water at room temperature was filled in it so as to reach the sternum process of the animals. The animals were subjected to stress session in such cages by immersing them, daily $2 \mathrm{hr}$ for the duration of 4 weeks. Drug treatments were given to the animals in group 1 during 10 days recovery period and were subdivided in 5 groups (A, B,C,D and E). Animals in Group $A(n=6), B(n=6), C(n=6)$ and $\mathrm{D}(\mathrm{n}=8)$, received $\mathrm{rH}-\mathrm{EPO}$ in the dose of $1000 \mathrm{IU} / \mathrm{kg}, 2000 \mathrm{IU} / \mathrm{kg}$, $4000 \mathrm{IU} / \mathrm{kg}$ and vehicle respectively by subcutaneous route every alternate day. Group E $(\mathrm{n}=6)$ received the Venlafexine $(40 \mathrm{mg} / \mathrm{kg}$, i.p) only on tenth day one hour before conduction of actual behavioural tests. Recovery period was given to avoid influence of recent stress session and to study long-term consequences of chronic stress on behaviour of animals [11]. The mean ridding time for animals subjected to rotarod (ten $\mathrm{cm}$ diameter, $20 \mathrm{rpm}$ ) test was used as a parameter for evaluation of behavioural performance during and after stress regimen.

\section{Effect of various antidepressants and receptor agonists/ antagonists in combination with rH-Epo in tail suspension test}

In the next set of experiments, we investigated interaction of $\mathrm{rH}$ Epo with standard antidepressant drugs such as imipramine (dual reuptake inhibitor), fluoxetine (selective serotonin reuptake inhibitor SSRI), venlafaxine (dual reuptake inhibitor of serotonin and epinephrine) and clorgyline (selective monoamine oxidase-A inhibitor). For this purpose rH-Epo and all other antidepressants were administered simultaneously at their sub-effective doses and screened for their antidepressant activity in tail suspension test. Doses studied were $\mathrm{rH}$-Epo (250 IU/kg s.c.), Imipramine ( $2.5 \mathrm{mg} / \mathrm{kg}$ i.p.), Fluoxetine (5 mg/kg i.p.), Venlafaxine ( $2 \mathrm{mg} / \mathrm{kg}$ i.p. $)$ and chlorgyline $(125 \mu \mathrm{g} / \mathrm{kg}$ i.p.). The doses of the drugs used were selected according to earlier studies conducted in our laboratory and as reported in the literature [12].

In further studies we investigated the interaction of $\mathrm{rH}$-Epo with agonist and antagonist of receptors involved in depression such as alpha2 and beta adrenoreceptor, 5-HT 1A/1B receptor and dopamine receptor using tail suspension test. In the first set of experiments, animals were divided in six groups and pre-treated with therapeutic dose of $\mathrm{rH}$ - Epo i.e.1000 IU/kg (18 hrs before test). First group received Pindolol (10 mg/kg), second group received Clonidine $(0.15$ $\mathrm{mg} / \mathrm{kg}$ i.p.), and third group received Haloperidol ( $2 \mathrm{mg} / \mathrm{kg}$ i.p.) along with their respective standard positive control without $\mathrm{rH}$ - Epo pretreatment and tested for their effect in tail suspension test. In second set of experiments, animals were pre-treated with sub-therapeutic dose of $\mathrm{rH}$-Epo i.e. $250 \mathrm{IU} / \mathrm{kg}$ s.c. (18hrs before test) and then injected with sub-therapeutic dose of Yohimbine $(10 \mathrm{mg} / \mathrm{kg}$ i.p.) and tested for combined effect in tail suspension test [12].

\section{Statistics}

Results were expressed as Mean \pm SEM and the data was analyzed by one-way or two-way ANOVA, followed by post- Turkey test and Paired $\mathrm{T}$ test wherever appropriate. $\mathrm{p}<0.05$ was considered statistically significant.

\section{Results}

\section{Effect of rH-Epo on acute stress induced in mice}

rh-Epo produced decrease in total immobility time (seconds) with respect to vehicle control group in both forced swim test and tail suspension test in mice as shown in Figures 1 and 2 at the 18th hour of administration. However effect of $\mathrm{rH}$-Epo was not found to be dose dependant. $\mathrm{rH}$-Epo at the dose of $250 \mathrm{IU} / \mathrm{kg}$ did not alter total immobility time of mice as compared to vehicle control in both the models. 

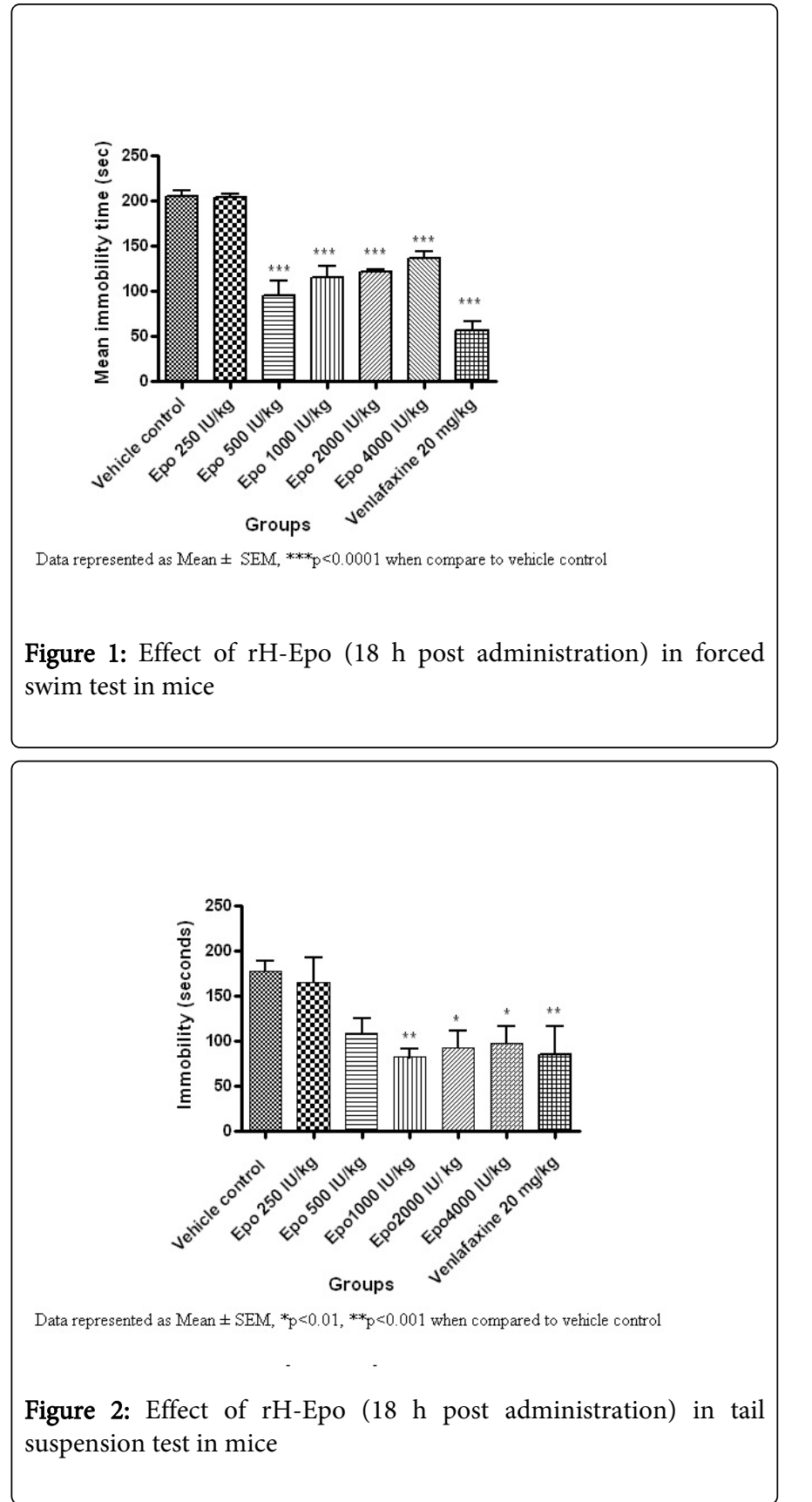

\section{Effect of rH-Epo treatments on rotarod activity of chronically stressed rats}

After ten days of recovery period (i.e. four week stress + ten days recovery period), in which animals with chronic stress received alternate day treatment of $\mathrm{rH}$-Epo at doses of $1000 \mathrm{IU} / \mathrm{kg}, 2000 \mathrm{IU} / \mathrm{kg}$ and $4000 \mathrm{IU} / \mathrm{kg}$. Animals showed improvement in rotarod activity at all three doses. Dose dependency was not seen in this activity (Figure 3). Group treated with $\mathrm{rH}-\mathrm{Epo} 1000 \mathrm{IU} / \mathrm{kg}$ animals showed maximum and statistically significant increase in rotarod performance as compared to other doses of rH-Epo. Group treated with Venlafaxine, showed significant increase in rotarod activity of rat as compared to that of positive control group as shown in Figure 3.

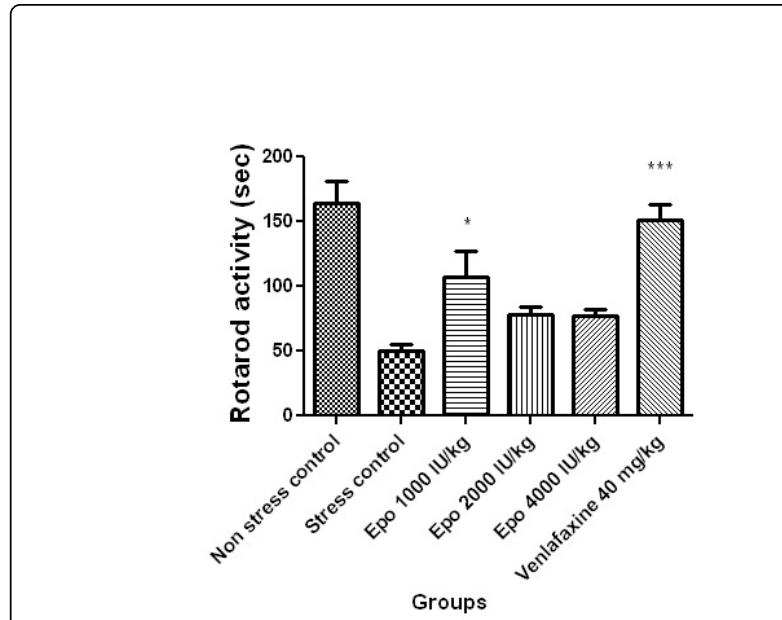

Data represented as Mean \pm SEM, ${ }_{p}<0.01, * * * *_{p}<0.0001$ when compared to stress control

Figure 3: Effect of rH-Epo treatment on rotarod activity of chronically stressed rats

\section{Effect of various antidepressants and receptor agonists/} antagonists in combination with rH-Epo in tail suspension test

Table 1 shows that pretreatment of mice with sub therapeutic dose of $\mathrm{rH}$-Epo (250 IU/kg s.c.) upon treatment with sub therapeutic doses of Venlafaxine (two $\mathrm{mg} / \mathrm{kg}$ i.p.), Imipramine (2.5 $\mathrm{mg} / \mathrm{kg}$ i.p.), Fluoxetine (five $\mathrm{mg} / \mathrm{kg}$ i.p.), Clorgyline $(0.125 \mathrm{mg} / \mathrm{kg}$ i.p.) significantly augmented antidepressant activity in tail suspension test.

\begin{tabular}{|c|c|}
\hline Group I & $\begin{array}{l}\text { Mean immobility time (sec) } \pm \\
\text { S.E.M. }\end{array}$ \\
\hline Vehicle control & $214 \pm 23.60$ \\
\hline rH-Epo (250 IU/kg, s.c.) & $212.2 \pm 21.68$ \\
\hline Venlafaxine (2 mg/kg). & $202.4 \pm 25.85$ \\
\hline Imipramine $(2.5 \mathrm{mg} / \mathrm{kg})$ & $199 \pm 22.13$ \\
\hline Fluoxetine (5 mg/kg) & $201 \pm 21.37$ \\
\hline Clorgyline $\quad(0.125 \mathrm{mg} / \mathrm{kg})$ & $213 \pm 15.11$ \\
\hline rH-Epo ( $250 \mathrm{lU} / \mathrm{kg}) \pm$ venlafaxine $(2 \mathrm{mg} / \mathrm{kg})$ & $82 \pm 8.51^{* * *}$ \\
\hline $\begin{array}{l}\text { rH-Epo }(250 \quad \text { IU } / \mathrm{kg}) \quad \pm \text { Imipramine } \quad(2.5 \\
\mathrm{mg} / \mathrm{kg})\end{array}$ & $113.33 \pm 10.05^{\star \star *}$ \\
\hline rH-Epo $(250 \mathrm{IU} / \mathrm{kg}) \pm$ Fluoxetine $(5 \mathrm{mg} / \mathrm{kg})$ & $96.5 \pm 20.44^{* * *}$ \\
\hline $\begin{array}{l}\text { rH-Epo }\left(\begin{array}{lll}250 & \mathrm{IU} / \mathrm{kg}\end{array}\right) \pm \text { Clorgyline }(0.125 \\
\mathrm{mg} / \mathrm{kg})\end{array}$ & $154.17 \pm 22.23^{\star * *}$ \\
\hline \multicolumn{2}{|l|}{ Group II } \\
\hline Vehicle control & $186.33 \pm 1.34$ \\
\hline rH- EPO(1000 IU/kg, s.c.) & $92 \pm 1.48$ *** \\
\hline Pindolol (10 mg/kg) & $183.33 \pm 1.42$ \\
\hline
\end{tabular}




\begin{tabular}{|c|c|}
\hline Clonidine $(0.15 \mathrm{mg} / \mathrm{kg})$ & $212 \pm 2.14^{\star \star \star}$ \\
\hline rH-Epo(1000 IU/kg) \pm Pindolol $(10 \mathrm{mg} / \mathrm{kg})$ & $212 \pm 3.56^{\star \star *}$ \\
\hline $\begin{array}{l}\mathrm{rH}-\text { Epo } \\
\mathrm{mg} / \mathrm{kg})\end{array}$ & $138.66 \pm 3.99^{* * *}$ \\
\hline \multicolumn{2}{|l|}{ Group III } \\
\hline Vehicle control & $204.66 \pm 4.63$ \\
\hline Haloperidol (2 mg/kg) & $311.83 \pm 2.35^{\text {***}}$ \\
\hline $\begin{array}{l}\mathrm{rH}-\text { Epo } \\
\mathrm{mg} / \mathrm{kg})\end{array}$ & $259.16 \pm 4.67^{* * *}$ \\
\hline Yohimbine (10 mg/kg) & $203.8 \pm 8.51$ \\
\hline rH-Epo $(250 \mathrm{lU} / \mathrm{kg}) \pm$ Yohimbine $(10 \mathrm{mg} / \mathrm{kg})$ & $155.66 \pm 4.84^{\star \star \star}$ \\
\hline
\end{tabular}

Table 1: Effect of pretreatment of $\mathrm{rH}$-Epo on sub therapeutic doses of standard antidepressants/drugs in tail suspension test of mice

Pindolol (10 mg/kg i.p.) when administered to mice showed no changes in immobility time period as compared to control. However Pindolol (ten $\mathrm{mg} / \mathrm{kg}$ ) administered to animals pretreated with $\mathrm{rH}$-Epo $(1000 \mathrm{IU} / \mathrm{kg})$ completely blocked the antidepressant activity of $\mathrm{rH}$-Epo in tail suspension test of mice as shown in Table 1.

Clonidine at the dose of $0.15 \mathrm{mg} / \mathrm{kg}$ i.p., significantly induced depression in mice as compared to vehicle control. This clonidine induced depression was partially reversed by $\mathrm{rH}-\mathrm{Epo} 1000 \mathrm{IU} / \mathrm{kg}$ as shown in Table 1.

Haloperidol (two $\mathrm{mg} / \mathrm{kg}$ ) itself induced depression like condition in experimental animals . Co-administration of $\mathrm{rH}-\mathrm{Epo} 1000 \mathrm{IU} / \mathrm{kg}$, reduced antidepressant effect of $\mathrm{rH}$-Epo. However there was no complete blockade of antidepressant action (Table 1).

Yohimbine $(10 \mathrm{mg} / \mathrm{kg})$, did not show any effect on immobility time of mice in tail suspension test as compared to control. But in combination with sub therapeutic dose of $\mathrm{rH}$-Epo $(250 \mathrm{IU} / \mathrm{kg})$ same dose of yohimbine reduced immobility time as shown in Table 1 .

\section{Discussion}

The tail suspension test and forced swim test were studied as a facile means of evaluating potential antidepressants as well as to investigate the mechanism underlying the action of antidepressants. The immobility displayed by rodents when subjected to an unavoidable and inescapable stress has been hypothesized and proved to reflect behaviour despair, which in turn reflects depressive disorders in human and is amenable to reversal by antidepressant drugs [13,14].

In present study, subcutaneously administered rH-Epo induced antidepressant like effect in both forced swim test and tail suspension test. This was in conformance with the clinical studies done showing the effectiveness of $\mathrm{rH}$-Epo in treatment resistant depression [15]. However, the effect was not dose dependent and was found to saturate between $2000 \mathrm{IU} / \mathrm{kg}$ and $4000 \mathrm{IU} / \mathrm{kg}$ dose. Percentage reduction in the immobility duration of $1000 \mathrm{IU} / \mathrm{kg} \mathrm{rH}$-Epo was comparable with standard venlafaxine in case of tail suspension test; similarly $500 \mathrm{IU} / \mathrm{kg}$ $\mathrm{rH}$-Epo was comparable with standard venlafaxine in case of forced swim test.

It is well known that depressive state is mainly produced by deficiency of norepinephrine, serotonin and dopamine in the brain.
The therapeutic effects of antidepressants are related to either preventing the reuptake (Tricyclic antidepressants (TCA's),Selective serotonin reuptake inhibitors(SSRI) and selective norepinephrine reuptake inhibitors (SNRI)\} or inhibiting metabolism \{(Monoamine oxidase inhibitors (MAOIs) $\}$ of neurotransmitters. Likewise this study was aimed to reveal the antidepressant potential of $\mathrm{rH}$-Epo, acting either by increasing availability of monoamines at synapses or by promoting the synthesis of monoamine neurotransmitters [16].

Number of studies has indicated that brain of depressed patients and suicide victims show increased expression of 5HT2A receptors. Immunolabelling studies in chronically depressed rats have shown that 5HT2A receptors are increased in frontal cortex and decreased in hippocampus and hypothalamus of rat brain [17]. In rats receiving chronic predictable stress, 5HT1A agonists like 8-OH DAPT is not fully active as antidepressant indicating the down regulation of 5HT1A receptors [18]. All these findings confirm that chronic stress induced depression is attributed to up-regulation of 5HT2A receptors and down regulation of $5 \mathrm{HT} 1 \mathrm{~A}$ receptors in the brain.

Impairment of rotarod performance in chronically stressed rats is an attribute of stress induced depression and is advanced with the chronic stress regimen despite the rats having the ability to acquire habituation or adaptation to the stressor [19].

Chronic stress induced impairment of rotarod performance was significantly ameliorated by the alternate day treatment of $\mathrm{rH}$-Epo over the ten days recovery period. This activity was also not found to be dose dependant with considerable saturation at $4000 \mathrm{IU} / \mathrm{kg}$. The percentage improvement of rotarod activity in animal groups treated with $1000 \mathrm{IU} / \mathrm{kg}$ and $2000 \mathrm{IU} / \mathrm{kg} \mathrm{rH}$-Epo was found to be comparable with that of positive standard Venlafaxine $(40 \mathrm{mg} / \mathrm{kg})$.

Rotarod performance impairment in chronically stressed rats is implication of depressive behavioural state caused by serotonergic dysfunction. Further examination on this basis have revealed that extracellular concentration of 5-HT in brains of chronically stressed rats is less than that of normal non stressed control rats [10]. rH-Epo ameliorated this depressive symptom of rotarod impairment, indicating that $\mathrm{rH}$-Epo treatment either up-regulate the serotonergic system or increase availability of serotonin and other neurotransmitters in the synapse.

Further studies showed that rH-Epo pretreated animals when administered with sub therapeutic doses of various standard antidepressants, reduced immobility time in tail suspension test of mice. This potentiation of antidepressant activity due to $\mathrm{rH}$-Epo pretreatment would be due to either increased bioavailability of monoamines in synapse or increased receptor sensitivity, any case in which much more detailed mechanistic studies need to be implemented.

This effect was very prominent in case of Fluoxetine (Selective serotonin reuptake inhibitor) and Venlafaxine (atypical antidepressant) than Imipramine (tricyclic antidepressant) and Clorgyline (MAOI's), indicating involvement of serotonergic system as the primary mechanism in antidepressant action of rH-Epo.

Pindolol, a 5-HT1A/1B receptor antagonist fully blocked the antidepressant effect of $\mathrm{rH}$-Epo strengthening the possibility of involvement of 5-HT1 receptor in antidepressant action of $\mathrm{rH}-\mathrm{Epo}$ [20]. Pindolol is also non selective $\beta$ adrenoreceptor blocker. But this action is unlikely to be related with the mode of action of $\mathrm{rH}-\mathrm{Epo}$, as $\beta$ adrenoreceptor blockers are not known to cause CNS depression [21]. 
Partial reversal of clonidine, an alpha2 adrenoreceptor agonist induced depression by rH-Epo indicates the involvement of noradrenergic system [22].

Yohimbine, selective $\alpha 2$ adrenoreceptor blocker when given to mice pretreated with sub therapeutic dose of $\mathrm{rH}-\mathrm{Epo}$, considerably reduced the immobility time period in tail suspension test. But this reduction in immobility time period was not found to be comparable either with response of $\mathrm{rH}$-Epo alone or with standard antidepressant. These results indicate limited involvement of noradrenergic system in antidepressant action of $\mathrm{rH}$-Epo [12].

Haloperidol, a dopaminergic D2 receptor blocker when administered to mice significantly increased immobility duration in tail suspension test. But when injected to animals pretreated with $\mathrm{rH}$ Epo, mean immobility time reduced to some extent. But this reduction in immobility time was not comparable to that of $\mathrm{rH}$-Epo alone or standard antidepressant. This indicated that dopaminergic system is having limited involvement in antidepressant action of $\mathrm{rH}$-Epo. It could be possible that induction of depressive symptoms by haloperidol and antidepressant effects of rH-Epo (though acting through serotonergic and/or noradrenergic systems) is compensating each other.

The results lead to suggest that rH-Epo has significant antidepressant like activity in acute and chronic stress induced depression. This activity may be due to enahanced activity of the serotonergic system or increased availability of monoamines such as serotonin and noradrenaline in synapse.

However further specific interaction studies with selective serotonergic receptor agents are needed to implicate the exact antidepressant mechanism of rH-Epo, which are being planned.

Conventional therapy of depression is associated with chronic administration of TCAs or MAOIs. Therapy with TCAs leads to sedation, weight gain, and hypotension. In the elderly, this is a particular problem, since it can result in fainting or falls. SSRIs and other agents with 5-HT-potentiating activity can interact dangerously or even fatally with MAO inhibitors leading to "serotonin syndrome" [23] and most commonly occur in patients receiving combination therapy with two or more serotonergic agents.

In light of the above undesirable effects with the existing therapy, the inclusion of rH-Epo in conventional therapy of depression may prove beneficial by decreasing these side effects and thus provide newer target in the therapy.

\section{Acknowledgement}

Authors are thankful to Dr Kala Suhas Kulkarni, Mumbai; and Dr. Yati Chugh, Managing Director, Lotus Labs Pvt Ltd. Bangalore.

\section{References}

1. Anonymous. Depression: management of depression in primary and secondary care. Clinical guideline 23. National Institute of Clinical Excellence. London: NICE; 2004.

2. Lappin $\mathrm{T}$ (2003) The cellular biology of erythropoietin receptors. Oncologist 8 Suppl 1: 15-18.

3. Hillman S (2001) Hematopoietic agents. Goodman \& Gilmanâ€ ${ }^{\mathrm{Tm}} \mathrm{s}$ The Pharmacological basis of therapeutics. 10th Edition: 1488â€“1491.
4. Yatsiv I, Grigoriadis N, Simeonidou C, Stahel P, Schmidt O, et al (2005) Erythropoietin is neuroprotective, improves functional recovery, and reduces neuronal apoptosis and inflammation in a rodent model of experimental closed head injury. The FASEB Journal 19: 1701-03.

5. Jelkmann W (2005) Effects of erythropoietin on brain function. Curr Pharm Biotechnol 6: 65-79.

6. Steru L, Chermat R, Thierry B, Simon P (1985) The tail suspension test: a new method for screening antidepressants in mice. Psychopharmacology (Berl) 85: 367-370.

7. Porsolt RD, Bertin A, Jalfre M (1977) Behavioral despair in mice: a primary screening test for antidepressants. Arch Int Pharmacodyn Ther 229: $327-336$.

8. Lucki I (1997) The forced swimming test as a model for core and component behavioral effects of antidepressant drugs. Behav Pharmacol 8: 523-532.

9. Bhattacharya SK, Bhattacharya A, Sairam K, Ghosal S (2000) Anxiolyticantidepressant activity of Withania somnifera glycowithanolides: an experimental study. Phytomedicine 7: 463-469.

10. Mizoguchi K, Yuzurihara M, Ishige A, Sasaki H, Tabira T (2002) Chronic stress impairs rotarod performance in rats: implications for depressive state. Pharmacol Biochem Behav 71: 79-84.

11. Vollmayr B, Henn F (2003) Stress models of depression. Clinical Neuroscience Research 3: 245-251.

12. Dhir A, Kulkarni SK (2007) Effect of addition of yohimbine (alpha-2receptor antagonist) to the antidepressant activity of fluoxetine or venlafaxine in the mouse forced swim test. Pharmacology 80: 239-243.

13. Wang R, Xu Y, Wu HL, Li YB, et al. (2008) The antidepressant effects of curcumin in the forced swimming test involve 5-HT1 and 5-HT2 receptors. Eur J Pharmacol 578: 43-50.

14. Borsini F, Meli A (1988) Is the forced swimming test a suitable model for revealing antidepressant activity? Psychopharmacology (Berl) 94: 147-160.

15. Miskowiak KW, Vinberg M, Harmer CJ, Ehrenreich H, Knudsen GM, et al. (2010) Effects of erythropoietin on depressive symptoms and neurocognitive deficits in depression and bipolar disorder. Trials 11: 97.

16. Graeff FG, Guimarães FS, De Andrade TG, Deakin JF (1996) Role of 5HT in stress, anxiety, and depression. Pharmacol Biochem Behav 54: 129-141.

17. Dwivedi Y, Mondal A, Payappagoudar G, Rizavi H (2005) Differential regulation of serotonin $(5 \mathrm{HT}) 2 \mathrm{~A}$ receptor m-RNA and protein levels after single and repeated stress in rat brain: role in learned helplessness behaviour. Neuropharmacology 48: 204-214.

18. Przegaliaski E, Moryl E, Papp M (1995) The effect of 5-HT1A receptor ligands in a chronic mild stress model of depression. Neuropharmacology 34: 1305-1310.

19. Ferretti C, Blengio M, Gamalero SR, Ghi P (1995) Biochemical and behaviour changes induced by acute stress in a chronic variate stress model of depression: the effect of amitriptyline. Eur J Pharmacol 280: 19-26.

20. Ying XU, Bao-Shan Ku, Hai- Yan Yao, Yan Hua Lin, Xing MA, et al. (2005) The effect of Curcumin on the depressive like behaviour in mice. Eur J Pharmacol. 518: 40-46.

21. Bourin M, Colombel MC, Redrobe JP, Nizard J, Hascoët M, et al. (1998) Evaluation of efficacies of different classes of antidepressants in the forced swimming test in mice at different ages. Prog Neuropsychopharmacol Biol Psychiatry 22: 343-351.

22. Parale MP, Kulkarni SK (1986) Clonidine--induced behavioural despair in mice: reversal by antidepressants. Psychopharmacology (Berl) 89: 171-174.

23. Lazarou J, Pomeranz BH, Corey PN (1998) Incidence of adverse drug reactions in hospitalized patients: a meta-analysis of prospective studies. JAMA 279: 1200-1205. 